\title{
Political Budget Cycles At Subnational Level: Evidence From The Indonesian Simultaneous Regional Election In 2015
}

\author{
Setyo Hari Priyono ${ }^{1}$ \\ Ministry of National Development Planning/Bappenas - Indonesia \\ Natascha Wagner ${ }^{2}$ \\ Institute of Social Studies-Erasmus University of Roterdam - Netherlands
}

\begin{abstract}
This study examines the existence of local budget utilization behaviour by incumbents who have politically interested policies, since they have motive to attract prospective voters. This study focuses on 254 provincial and districts/cities in Indonesia which held simultaneous regional head election in 2015. It analyses targeted expenditures that have highly visible to please voters, and allegedly affect vote-share results, such as budget deficits, total spending, investment spending, discretionary funds include its sub components: grants, social aids, and financial aids. According to the results obtained, there is no indication of politically driven fiscal policy by incumbent candidates in almost all spending categories. However, there is a positive and significant relationship between the regions that have incumbents and grant expenditure subcategory behaviour. This finding indicates that this category expenditure is still popular among incumbents to stimulate citizens and gain sufficient vote-share later on.
\end{abstract}

Keywords: political budget cycles; fiscal spending policy; simultaneous local elections; indonesia.

\footnotetext{
${ }^{1}$ Setyo Priyono is a Planner Staff at Ministry of National Development Planning/Bappenas and a Post Graduate Student Linkage Program at PPIE-FEUI and ISS-EUR. Email address: setyo.hp@ bappenas.go.id.

${ }^{2}$ Natashca Wagner is an Associate Professor at International Institute of Social Studies-Erasmus University of Rotterdam, The Hague.
} 


\title{
Political Budget Cycles At Subnational Level: Evidence From The Indonesian Simultaneous Regional Election In 2015
}

\author{
Setyo Hari Priyono and Natashca Wagner
}

\section{Introduction}

Existing studies of the existences of fiscal policy behavior that induced by political motivation has been developed among scholars both in economics and political science. There is an assumption that politicians who run government and eligible to compete in the next period election behave more opportunistic. They tend to reduce revenues or increase spending particularly if they are running for elections for the second time. One of the reasons the incumbents' try to attract voter, by sending 'the good signal' that reflect their performance (Nordhaus, 1976; Roggof, 1990; and Baskaran et al., 2016). Many scholars argue that politically motivated fiscal policy behaviour appears because of lack of information by voters and leads the political leaders to utilize the budget aligned with their vested interests. Rogoff (1990) and Shi and Svensson (2003) argues that asymmetric information leads moral hazard and induced politicians to apply opportunistic spending to attract voters. This fiscal action reflects a persistence behaviour in economic policies induced by the timing of elections.

Mix outcome has raised, whether this political events like elections has effect on budget implementation or not. A series of empirical studies showing the importance of budget spending when re-election is possible. Galli and Rossi (2002); Chortareas et al. (2016); and Klein and Sakurai (2015) show that government expenditure increases around election time, in particular, if the incumbents run for the second term. Incumbents will attempt to increase their popularity with voters by employing the budget strategically. In other words, incumbent politicians may try to increase their re-election probability through budget spending in certain budget lines. Specifically, in Indonesia, the local leaders who run re-election are thought to increase budget spending. Several studies find that the political motivated behaviour on budget spending is present in direct elections and relate to expenditure discretion categories such as donations and social assistance that need mayors or regents' discretionary control (Ritonga and Alam, 2010; and Sjahrir et al., 2013). These studies also noticed it has relation with the regions that has incumbent and run re-election for the second term. However, after amending MoHA Decree No. 32 of 2011 on Guidelines for Grant and Social Assistance sourced from APBD to Decree No. 39 of 2012 indicate that regional officers has shifted strategy to keep maintaining their image building and 'good signal' upon their voters (KPK, 2016).

This research will focus on the regional public expenditure policy instead of revenue side, that indicated has a relationship with election time. The local government has however remained reliant on the central government as evidenced by substantial intergovernmental transfer funds. In 2015, the intergovernmental transfer budget was 700,4 trillion rupiah, seeing a significant increase from 322,4 trillion rupiahs in 2010. According to the Law 23 of 2014 regarding Regional Government, there are three types of the fiscal transfer budget in Indonesia, which are revenue sharing $(\mathrm{DBH})$, general allocation subsidiary (DAU), and specific allocation funds (DAK). Brodjonegoro (2001) and Blondal (2009) also argue that the fiscal decentralization process in Indonesia focuses on expenditure decentralization 
rather than the revenue side. Therefore, this research will give more emphasizes on spending behaviour of the local government in election years.

By 2005 the election system in Indonesia was changed and the first direct elections held in all municipalities. The incumbents are allowed to complete their terms which ended at different time and years. After conducting and evaluating direct elections process for ten years, in 2015 Indonesian government and the House of Representatives agreed to promote regional elections simultaneously. Unfortunately, money politics, patronages, and political dynasties are still widespread in local politics and fuel corruption. Data from the Ministry of Home Affairs until December 2015 revealed that there are 343 of the head of municipalities that involved a legal case whether General Attorney, Police Office, or KPK (www.kompas. com 04/02/2015). Moreover, many incumbents' family members such as brothers, sisters, children, relatives, and even wives are running in elections that allegedly to extend family control (www.news.detik.com 22/01/2017).

This study will focus on 254 regions conducted election due to there are 14 newly formed regions. According to Indonesian regional elections result in 2015, from 98 regions that incumbents involved elections, showed that 69.01 percent of incumbents won, whether this phenomenon is whether this phenomenon is a political budget cycles presence or not still need further exploration.

It is important to analyse the sub-national levels of political budget cycles in Indonesia since regional governments particularly districts and cities are the closest administration to citizens who directly get the impact of their policies. However, although some beneficial effect of Indonesian fiscal decentralization on public services delivery (Simatupang, 2009 as cited in Muttaqin, 2017), another recent literature found that regional head direct election of local government decreased local government responsiveness in terms of public service provision (Kis-Katos and Sjahrir, 2014).

Another assumption is a politically driven of local budget utilization. It means, local budget misuse spending in some categories by the local head government often occurs approaching election year (Sjahrir et al., 2013; and Setiawan and Rizkiah, 2017). Sjahrir et.al, (2013) and Winoto and Falikhatun (2015) also find that incumbent regions act more opportunistic in order to gain voters sympathy. They tend to use the budget in particular in "discretionary budget subcategory" more excessive. Allegedly, they indicate allocate the budget without regard to performance background and reliable benchmarks but depends on their vested interests (Ritonga and Alam, 2010). It means, the local government budget tends to be allocated in "discretionary channel fund" instead of directly related to the society welfare improvement.

Unlike several studies on political cycles in Indonesia that only focus on the discretionary spending budget cyclical behaviour induced by election time (Ritonga and Alam, 2010; Sjahrir et al. 2013; Winoto and Falikhatun, 2015), this study also tries to capture other expenditures that might have relationship on the incumbents opportunistic behavior. Previous studies find that incumbents who are eligible to rerun in election have more ability and incentive to maximize their reelection prospect by utilizing some specific budget components that have links to attract electorates (Drazen and Eslava, 2010; Sjahrir et al., 2013; Klein and Sakurai, 2015). These spending categories are budget balances, total expenditure investment expenditure, discretionary funds, grants, social aids, and financial aids. 
Therefore, this study observes the occurrence of the cyclical economic behaviour in local government budget in the Indonesian simultaneous election in 2015. The study focuses on 254 provinces, districts and municipalities in Indonesia which held simultaneous direct local elections in 2015. Other 108 regions are added to examine whether the politicaleconomical cyclical also occurs in these regions regardless there is no simultaneous regional head direct election was held in 2015. The variety of local elections time implementation in each subnational level (provincial, districts and municipalities) expected to enhance interaction and identification of politically driven fiscal policies (Sjahrir et al. 2013). Meanwhile, in the simultaneous local election, the politically induces cycles might overlap with other time effects. The result from this study show evidence that incumbents who seeks for re-election utilize more in grants during the election year. They attentively try to broadcast their 'good image' earlier and get impression from electorates afterwards to enhance voteshare probability.

This study organized as follows. Chapter 1 Introduction that discuss the importance of the political budget cycles studies and some brief fundamental arguments on underlying mechanisms. Chapter 2 This chapter will discuss the theoretical of political budget cycles and empirical evidences as well. 3. Data and Methodology will detail variables used in the study including sources of the data, and the model used to answer research questions. Chapter 4 presents the main empirical results and how they relate to the theoretical background exposed in the earlier chapter. Chapter 5. Conclusion will summarize the findings and also try to give some suggestion for improving work in the future.

\section{Literature Review}

Politically induced fiscal policy outcome has closely related to two terms of politician behaviour as a motivation basis of politicians, first, opportunistic behaviour models mention that incumbent politicians maximize the budge as their opportunity to enhance their voteshare. The last term is partisan politicians that the behaviour can be shifted relies on the ideological elected parties (Drazen and Eslava, 2010; and Klein and Sakurai, 2015). Regarding incumbents' opportunistic behavior, Nordhaus (1975) initially introduced a theory of political business cycles by proposing a model in which incumbents would utilize the macroeconomic policy (balance deficits policy, unemployment policy, and inflation policy) in order to gain electoral advantages. This early model emphasizes that the incumbent intentionally would secure re-election by optimizing the vote share expectation. The model also assumes that the voters will record and evaluate the incumbent's past performance. Therefore, the incumbents attempt to create the most desirable economic conditions before elections by applying expansionary fiscal policies to stimulate economy growth and create "constructive" circumstances (Nordhaus 1975).

Another concept was introduced by Rogoff and Sibart (1988) and Rogoff (1990) when narrowing the scope of discussion from macroeconomic perspective to only fiscal policy. This strand of the literature assumes that fiscal cyclical behaviour can be shown by given an equilibrium signalling interpretation from the electorate to describe unobserved current government performance. This literature assumes that voters have rational expectations but have difficulties to monitor the incumbent's competency level due to asymmetric information (Rogoff and Sibart 1988). In other words, in these models, signalling is the driving force behind 
incumbents' behaviour on fiscal policy spending that aim to re-run election. Incumbents use government spending to increase fiscal policy performance prior to election time to signal competence to the electorate.

Rogoff (1990) works' version of politically motivated budget policy induced by asymmetric information of voters to evaluate incumbent's performance correctly. A model to describe leaders' action who have desire to be reappointed and act opportunistically to send good signal that they are competence. Voters as the opposite side, wants to elect them but have limited information to measure their performance, so that evaluate from the incumbents' previous period performance. This condition leads to 'moral hazard' by Shi and Svensson (2003), that argue the incumbent candidates that has desire to join re-election may act opportunistically regardless of the fact that most electorates know the government's policy, since some electorates are uninformed. The larger the number of electorates that fail to distinguish between election-induced fiscal policy manipulations and the incumbent's competence, the more incumbents may profit from boosting expenditures prior to an election. In equilibrium, expenditures targeted to particular electorates are higher in an election period than in a non-election period. Swing voters will rationally vote for incumbents who provide more targeted expenditures even when they know that such expenditures may be electorally motivated.

Most political budget cycles studies in particular subnational level, the dependent variable is a measure of fiscal policies, whether local government spending or revenues. Klein (2010) stated that the variable Y of political budget cycles study is fiscal policy (total government spending or expenditures on development projects), and the explanatory variable is a dummy reflecting an election period. Likewise, Chortareas et al. (2016) and Benito, et al. (2012) who have used fiscal variables (capital and current spending, and revenues) as their dependent variables to examine the political budget cycles existences in Greece and Spain municipalities respectively. The voters have preferences for high level of spending in particular the public goods or related to their welfare such roads, transport systems, schools, and hospitals (Klein 2010). In addition, Sjahrir et al. (2013) models showed that donation and social assistance budget spending would increase the incumbent leader's popularity among the voters. Moreover, it also will enhance their probability when the political budget cycles presence (Klomp and Haan 2013; and Ballaguer-Coll et al. 2015).

Chortareas et al. (2016) approach model that adapted from many scholars to examine political budget cycles existence through fiscal variables that include total expenditures and revenues, and other vector variables such as a number economic (government subsidies), demographic (population) and political (party's ideology) explanatory variables. Similarly, Klein (2010) offers model to examine the existence of political budget cycle through the real government spending per capita. He also accounting other control variables for other political determinants of public expenditure, such as the former election result of the local head's political party vote-share, the party dummies indicators whether the incumbent's party is the same as the former leaders not only local but also national, and the log population. He also proposes the probability of the local incumbent leaders being re-elected through the variation in real government spending per capita, and other control variables such as the variation of per capita revenues, and the fiscal deficit measurement (Klein 2010).

Specifically, at the local governments in Indonesia, Ritonga and Alam (2010) find 
that the allocation of grant and society support expenditure in incumbent regions during the election year is higher than prior the elections. As mentioned, Sjahrir et al. (2013) analyze the political budget cycles effect for indirect and direct elections in Indonesia and find that significant political budget cycles exist in Indonesian districts only for direct election, and that the political budget cycles are significantly stronger when incumbents run for re-election. Winoto and Falikhatun (2015) investigate the possibility of misuse of discretionary funds in local governments' budget by incumbents before election and find indication that more proportion of budget allocation on grant and social aid related to incumbent before the local election in 2015.

Regarding simultaneous regional election, it implementing in order to reduce the risk of disruption and disturbance from areas that do not hold elections on that day. Moreover, simultaneous regional elections are more efficient economically, more focused to capture what local people needs, and easier to be assessed compared to separate elections (www.idea.int 14/02/2017); www.globalindonesianvoices.com 26/11/2015; www.netralnews. com 09/01/2017). During ten years of direct regional head election implementation since 2005 , around 1,500 regional elections conducted in Indonesia with various completion tenure periods of head of regions leading to high cost and inefficiency (http://www.thejakartapost. com 09/09/2014).

Law No. 8 of 2015 mandates that from 2015 to 2018, local elections have to be implemented every 5 (five) years simultaneously on the same date throughout the territory of the Republic of Indonesia (Republic of Indonesia 2015). The election on 9 December 2015 was only one of the three rounds of simultaneous regional elections in Indonesia covering 269 regions in Indonesia. Based on data from the Directorate General of Regional Autonomy, MoHA, regional head elections will be implemented simultaneously in 269 regions which consist of 170 districts, 26 cities and eight provinces in Indonesia on 9 December 2015 (Ministry of Home Affairs 2014). Following the first event in 2015, there have been other two rounds after regional direct elections in 2015, which was held on February 2017 in 101 regions, and followed by the third round which will be held in June 2018 in 171 regions (General Elections Commission 2015).

The current local leaders, whether the governor, the mayor, and the regent can be re-elected for the second period and called as incumbent. However, there is an unclear definition regarding incumbent in Act on Regional Elections in Indonesia. Formally, the only explanation of incumbent terminology comes from the KPU Regulation No. 9 of 2015 on Governor, Regent, and Mayor Nomination. Article 1 section (19) states: “The Incumbent is the Governor or Vice Governor, Regent or Vice Regent, and Mayor or Deputy Mayor who is currently serving." However, The Supreme Constitutional Court has canceled the Law by Decision of The Supreme Constitutional Court number 100/PUU-XIII/2015 mentioning the prohibition of incumbent's relatives is against the constitution and human right. Therefore, regarding the incumbent terminology, this research will use the KPU regulation No. 1 section (19) definition instead of the further explanation from the KPU formal letter, to analyse the relations between incumbencies to local budget expenditure behaviour particularly in an election year. 


\section{Data And Methodology}

This research uses a data set of public spending and deficits of districts and municipalities in Indonesia which held simultaneous direct head local elections over the period 2011-2015. The unit of observation is the municipality level in Indonesia. Data related to local government expenditures was obtained from Directorate General of Fiscal Balance, Ministry of Finance report and Government Financial Statistics Regency/City from Statistics Indonesia (Central Statistics Agency/ BPS). The demographic data for control variables includes population and adult literacy rate, also obtained from 2010 Indonesia Population Census and its projection, and National Socioeconomy Survey (Susenas) respectively. Both data are gathered from BPS. Finally, political data consisting of timing and results of each local elections, the incumbents running for re-election, were obtained from various sources, including KPU, MoHA, and Perludem.

This study's hypothesis is constructed based on several previous studies as follow. First of all, Klein and Sakurai (2015) study that use the fiscal policy variables including budget balance, borrowing revenues, total expenditures, and investment expenditures to examine the effect of term limits on electoral cycles in Brazil Municipalities. Other studies by Sjahrir et al. (2013) and Chortareal et al. (2016) also reviewed the interaction between incumbents and opportunistic behaviour by utilizing certain fiscal variables in Indonesian and Greece municipalities respectively and adding demographic, and political variables as control.

In this research, I will propose a model to analyse the existences of political budget cycles by analysing such targeted expenditures that allegedly have effect on electoral purposes. Therefore, this study will adapt framework and model from previous typical model from Sjahrir et al. (2013) and Chortareas et al. (2016):

$$
y_{j i t}=\alpha+\beta_{j} y_{i j t-1}+\gamma_{1} \text { Elections }_{i t}+\gamma_{2} \text { 2Elections }_{i t} * \text { Incumbent }_{i t}+\delta X_{i k t}+\eta_{i}+\theta_{t}+u_{i j t}
$$

We estimate equation using the fiscal policy variables on the left-hand side, which are include budget deficits and total expenditures. We also examine the highly visible to the electorate expenditures such as investment expenditure and discretionary expenditures (consist of grants, financial assistance, and social aid spending). All dependent variables are expressed in logarithms excluding the budget balance in order to capture negative values. The vector $\mathrm{X}_{i k t} \mathrm{X}$ is control variables representing economic, demographic, and political variables that affect local budget spending policy. The main variable interest of this study is incumbent, a dummy variable to capture current incumbents for re-running reelection whether they apply an aggressive fiscal policy or not.

Moreover, other factor variables are included in this study to control such as GRDP per Capita; education rate of the people which is proxy by adult literacy rate (LitRate); population size (PopSize) by constructing a variable in logarithms as well; DisctrictArea; and Number of Villages to capture the characteristic of each regions. Regarding literacy rate, we exclude a demographic variable that represents the percentage of the population under 15 years old (\% Pop < 15), which is not eligible to vote in any elections. In other words, it represents adult literacy rate reflects the ability of people as the voters to evaluate as well as watch whether to elect or punish incumbents who apply excessive spending on their municipalities (Sjahrir et al., 2013). The log population, district area, and number of villages added since the adoption of the 'brand image building' strategy should become less effective 
as the size of the district's increase (Sjahrir, 2013; Chortareas et al., 2016). Notice the lagged of dependent variables before election in 2015 are applied. It is, therefore, usually to capture fiscal persistency over time and the political budget cycle existences (Sakurai and Klein, 2015). Finally, the variable denotes $u_{i j t}$ represents the regression error term.

This study utilizes panel data, in which each object (districts/cities) has one annual budget analysed each year. The unit of analysis is 254 regions that held a simultaneous direct election in 2015, excluding 15 newly-formed regions. The studies are also identical because every variable can have an impact on the outcome are the same across the five years analysis. Furthermore, the analysis is conducted using the same method each year which makes the studies share the same effect. Previous studies that focused on political budget cycles such as Sjahrir (2013), Ballaguel-Coll (2015) and Chortareas et al. (2016) also used Fixed Effect Model. Therefore, Fixed Effect Model is seen appropriate to use in this study, and controlling year and municipalities to capture spending persistency approaching election year.

\section{Result Analysis}

Descriptive analysis provides an overview of the basic features of the data that used in the research. This analysis also describes the modest synopses related to the observation (population or sample) as well as its measures. The descriptive statistics of this study is presented in Table 1.

Table 1. Descriptive Statistics (1)

\begin{tabular}{|l|l|l|l|l|l|}
\hline Variables & Obs & Mean & Std. Dev. & Min & Max \\
\hline Incumbent & 144 & 0.58 & 0.49 & 0 & 1 \\
\hline Reelected & 99 & 0.69 & 0.46 & 0 & 1 \\
\hline Adult Literacy Rate & 254 & 94.62 & 8.05 & 32.56 & 100 \\
\hline Population Size & 254 & 12.60 & 1.02 & 9.81 & 15.08 \\
\hline
\end{tabular}

Source: Dataset constructed by the author

Note: * in natural logarithm

The table shows a summary of all variables descriptive statistics that used in this study. According to STATA estimation of this study uses unbalanced data, the number of each observation will be varying in samples and variables. Total observations are 254 regions that held a simultaneous direct head election in 2015. First of all, statistical descriptive above shows that the mean value of incumbent is 0.58 , which means the regions held a simultaneous direct election that has incumbent who eligible rerun in election is about 58.0 percent or around 144 regions. Another fact is the incumbent that have eligibility to run re-election majority won the first simultaneous regional head direct election in 2015. The percentage of the incumbents being re-elected is around 69.0 percent or about 99 candidates. According to the table above, the mean of adult literacy rate in Indonesian regions held the concurrent election in 2015 is 94.62 percent which is sufficient high. However, disparity of literacy rate among municipalities still become obstacles where the lowest rate is only more than 32 percent mostly in eastern part of Indonesia regions. The descriptive statistics of fiscal variable in this study is presented in Table 2. 
Table 2. Descriptive Statistics (2)

\begin{tabular}{llllll}
\hline \multicolumn{1}{c}{ Variable } & Obs & Mean & Std. Dev. & Min & Max \\
\hline GRDP/Cap* & 254 & 3.284448 & 0.7540669 & 0.9678938 & 5.93629 \\
Budget Balance $_{\text {Total Expenditure* }}$ & 254 & 10.21342 & 1.362353 & 5.421271 & 13.38948 \\
Investment Exp* $^{*}$ & 254 & 13.98715 & 0.517021 & 13.07682 & 15.7288 \\
Discretionary Exp* & 254 & 12.50706 & 0.584913 & 10.85863 & 14.85243 \\
Grants Expenditure* & 254 & 11.60978 & 0.8307616 & 7.304655 & 13.34736 \\
Social Assistance Exp & 254 & 10.75022 & 0.71654 & 7.846889 & 12.58773 \\
Financial Assist Exp $^{*}$ & 254 & 8.020255 & 1.716219 & 2.890372 & 11.53818 \\
\hline
\end{tabular}

Source: Dataset constructed by the author

Note: * in natural logarithm

In terms of Regional GDP Per Capita, the mean value of GRDP per capita is 3.28 (in million rupiahs) and the standard deviation is 0.75 (in million rupiahs). According to the table for total expenditures, the mean value is 13.99 with standard deviation of 0.52 . Regarding the investment, expenditure has a mean value of 12.5 and the standard deviation is 0.58 . The summary of discretionary funds category for regions held a simultaneous direct election in 2015 are as follows.

Turning to the regression analysis, this sub chapter will discuss the existences of political budget cycles in regions that conducted simultaneous direct election in Indonesia in 2015. In general, most of the expenditure variables have positive and significant affect in terms of election, whether they have eligible incumbent for rerun election or not. However, in discretionary category expenditure shows that in regions that have re-runner incumbents during election in 2015 affect fiscal implementation. Table 4 will analyze whether there is budget cycles that induced by regional local election in 2015 .

Having captured a robust opportunistic behaviour regarding the finance of Indonesian municipalities approaching regional simultaneous local elections in 2015, we analyse local head executive behaviour on local fiscal performance. The main interest variable of this study is the interaction between incumbent and election time in 2015 (Incumbent* Election 2015) which reflecting incumbents' behavior on certain budget expenditures category during election year. Lagged dependent variables and controlling dummy year until three years before election identifies the budget utilization deviation between during election year compared to three years before election.

Table 3 above shows that Lagged Dependent Variables has a negative and significant effect on Budget Balance and Investment Expenditure (both at the 1\% level of significance). This result supports previous studies result such as Drazen and Eslava (2010), Veiga and Veiga (2011), and Winoto and Falikhatun (2015) studies in Colombian, Portuguese, and Indonesian municipalities, that mention these certain expenditures increased in election year compared to previous election. The table also confirm the persistence in most spending categories such total expenditure, investment expenditure, discretionary budget as an aggregation and in each category. Discretionary funds category is a total amount of grants, social assistance, and financial assistance spending. The above table result suggests that from budget year 2013 to 2015 has an increased from two years before elections at the $1 \%$ of significance level at these budget spending categories mentioned. This evidence supports the former parallel studies 
Table 3. The Existence of PBC Behaviour

\begin{tabular}{|c|c|c|c|c|c|c|c|}
\hline Variables & $\begin{array}{l}\text { Total } \\
\text { Expend. }\end{array}$ & Budget Balance & $\begin{array}{l}\text { Invest. } \\
\text { Expend. }\end{array}$ & $\begin{array}{l}\text { Discretionary } \\
\text { Funds }\end{array}$ & $\begin{array}{l}\text { Grant } \\
\text { Expend. }\end{array}$ & $\begin{array}{l}\text { Social Assist. } \\
\text { Expend. }\end{array}$ & $\begin{array}{l}\text { Financial } \\
\text { Assist. Expend. }\end{array}$ \\
\hline \multirow{2}{*}{$\begin{array}{l}\text { Lagged Dependent } \\
\text { Variables* }\end{array}$} & 0.041 & $-0.307^{\star * *}$ & 0.049 & -0.061 & $-0.129^{* * *}$ & -0.056 & -0.056 \\
\hline & $(0.099)$ & $(0.072)$ & $(0.042)$ & $(0.053)$ & $(0.045)$ & $(0.057)$ & $(0.079)$ \\
\hline \multirow[t]{2}{*}{ Election Total } & $-0.044^{* * *}$ & -0.254 & $-0.161^{\star * *}$ & $0.218^{* * *}$ & $0.706^{* * *}$ & -0.177 & -0.211 \\
\hline & $(0.013)$ & $(0.199)$ & $(0.032)$ & $(0.067)$ & $(0.087)$ & $(0.149)$ & $(0.141)$ \\
\hline \multirow{2}{*}{$\begin{array}{l}\text { Incumbent }{ }^{\star} \text { Election } \\
2015\end{array}$} & 0.004 & 0.383 & 0.017 & 0.004 & $0.278^{\star *}$ & -0.083 & 0.203 \\
\hline & $(0.026)$ & $(0.351)$ & $(0.047)$ & $(0.100)$ & $(0.139)$ & $(0.210)$ & $(0.260)$ \\
\hline \multirow{2}{*}{ GRDP Per Capita* } & $0.223^{* *}$ & 0.235 & 0.195 & 0.336 & -0.349 & -0.341 & $2.062^{\star *}$ \\
\hline & $(0.101)$ & $(0.756)$ & $(0.163)$ & $(0.304)$ & $(0.596)$ & $(0.657)$ & $(0.856)$ \\
\hline \multirow[t]{2}{*}{ Adult Literacy Rate } & 0.001 & 0.014 & 0.001 & -0.002 & -0.001 & 0.002 & -0.002 \\
\hline & $(0.001)$ & $(0.016)$ & $(0.002)$ & $(0.003)$ & $(0.006)$ & $(0.005)$ & $(0.012)$ \\
\hline \multirow[t]{2}{*}{ Population Size } & -0.046 & $-11.372^{*}$ & -0.729 & -1.728 & -1.904 & 1.000 & 0.834 \\
\hline & $(0.484)$ & $(5.986)$ & $(0.893)$ & (1.655) & $(2.493)$ & $(3.880)$ & $(3.654)$ \\
\hline \multirow[t]{2}{*}{ 2013.year } & $0.110^{* * *}$ & 0.074 & $0.164^{* * *}$ & $0.187^{* * *}$ & $0.290^{* * *}$ & $0.225^{*}$ & 0.043 \\
\hline & $(0.016)$ & $(0.175)$ & $(0.027)$ & $(0.051)$ & $(0.074)$ & $(0.124)$ & $(0.116)$ \\
\hline \multirow[t]{2}{*}{ 2014.year } & $0.212^{* * *}$ & $0.600^{* *}$ & $0.294^{* * *}$ & $0.445^{* * *}$ & $0.644^{* * *}$ & 0.202 & -0.039 \\
\hline & $(0.030)$ & $(0.241)$ & $(0.041)$ & $(0.072)$ & $(0.123)$ & $(0.168)$ & $(0.185)$ \\
\hline \multirow[t]{2}{*}{ 2015.year } & $0.379^{* * *}$ & 0.325 & $0.521^{* * *}$ & $0.953^{\star * *}$ & $0.566^{\star * *}$ & -0.122 & $1.006^{* * *}$ \\
\hline & $(0.045)$ & $(0.366)$ & $(0.060)$ & $(0.112)$ & $(0.180)$ & $(0.238)$ & $(0.265)$ \\
\hline \multirow[t]{2}{*}{ Constant } & $12.897^{* *}$ & $156.418^{* *}$ & $20.041^{*}$ & 32.064 & 35.792 & -2.798 & -6.753 \\
\hline & (6.159) & $(76.522)$ & $(11.221)$ & (20.897) & $(31.769)$ & (48.935) & $(46.157)$ \\
\hline $\mathrm{N}$ & 1448.00 & 844.000 & 1447.000 & 1446.000 & 1390.000 & 1331.000 & 1123.000 \\
\hline
\end{tabular}

Source: Author Estimation

*) In nature logarithm

Denote significance at the $* * * 1 \% ; * * 5 ; * 10 \%$ levels.

in Indonesia that local government will allocate more in this type of expenditure categories towards election years (Sjahrir et al., 2013; Winoto and Falikhatun, 2015).

The above result also suggest that the incumbent has affect discretionary expenditure particularly in discretionary funds spending in election year. The re-running incumbents behave opportunistically by promoting spending that need their subjectively discretion. Allegedly, this type of expenditures is important for re-runner candidates to beautify their self-image to attract the voters. This evidence also in line with the previous studies on budget spending electorally cycles mention that the incumbent that desire to be re-elected prefer to increases in these types of budget spending sub ccategories (Ritonga and Alam, 2010; Winoto and Falikhatun, 2015), by distributing donations and social assistance to their citizens (discretionary funds) during election time to attract the prospective voters. Interestingly, by disaggregating discretionary funds to detangles grants, social aids, and financial aids, show that all these sub components have insignificant effect on the opportunistic spending behavior by incumbents.

Turning to the control variables, we realize that Gross Regional Domestic Product per Capita consistently have a positive and significant effect total expenditure and financial aids expenditure (both at $1 \%$ level significant). It means, standard of living people in observed municipalities has positive effect on total expenditure of its government, meanwhile the level of citizen's income has influence on financial aids spending. However, the number of populations have insignificant effect on the amount of local government spending regarding 
political events.

According to these results shows that in one of discretionary expenditures sub categories (grants) still popular for the head local government to 'signal good image' upon their electorates. Another possibility reason why grant subcategory increases in the election time in 2015, is because the local governments have to finance the local election. The budget spending category for financing election comes from donations or grants expenditure subcategory, and it will be more significant in regions that have incumbents (KPU, 2017). In this way, an increase of amount in the grant expenditure in election year is inevitable. The regulation that mentions management of election activities fund sourced from APBD is the Decree of MoHA No. 44 of 2015 on Fund Management of Governor and Vice Governor, Regent and Vice Regent, and Mayor and Vice Mayor as amended by the Decree the Minister of Home Affairs No. 51/2015. This regulation regulates budgeting, implementation and administration, reporting and the accountability of budget utilization.

Finally, concerning there is no different effect of the incumbency on local budget policy in other type of budget components, Drazen and Eslava (2010) suggest that the last period incumbents will behave similarly with re-candidate incumbents because of: 1) An incumbent who cannot rerun election knows that his decision to raise the budget spending will affect his party's or the incumbent's preferred candidate reappointed probability; 2) The often have plan to involve another election in the upcoming year. Thus, this 'signal' will be captured by the electorates to examines their 'high-level competence'.

\section{Conclusion}

This study aims to prove empirically whether there is a budget cycles that induced by political motivation in the Indonesian simultaneous regional direct election in 2015. By analyzing budget balance, total spending, and spending categories that have highly visible to please prospective voters such as investment expenditure, discretionary funds as aggregate, and it disentangles: grants, social aid, and financial aid subcategory. The regression results show that election time has a positive and significant effect on local government spending. However, regarding incumbency influence, there is only a positive and significant effect on grants spending. Based on the result, shows that grants are still popular for the head local government to reflects their good image upon electorates. However, the facts that the local governments have to finance the local election and it mostly comes from grants expenditure should be concerned as well.

The future research is also necessary to pay attention to the previous election result to know the effect on the incumbents' vote-share; the relatives of the incumbents' that involve the election; and political affiliation when it comes to re-election probability, since the behaviour might be affect the result. A further research is also needed, to do a more in-depth investigation on the rational reason whether the opportunistic fiscal policy by the incumbents associated with enhancement of the probability of being re-elected or not. Another study related to Indonesian concurrence regional direct election in 2017 and 2018 is also strongly suggested to examine the sequence of the incumbency factor on local fiscal spending behaviour. 
Hence, this study results may encourage some policy recommendation. Firstly, the fact shows that a high level of budget transparency at municipality will reduce misuse of budget occurrence in some certain expenditure. Thus, in order to minimize ineffectiveness of budget utilization, we should improve transparency of budget management in all levels. At the meantime, restricted and improved the regulation is needed, not only related to the executive local government, but also donations allocation for political organization including political party. Another policy initiative is the election regulation should be revised.

\section{References}

Adityowati, P. (Last updated 17 April 2015) 'Kemendagri: Daerah Wajib Anggarkan Dana Pilkada' (a webpage of Tempo Media Group). Accessed August/20 $2017<$ https://m. tempo.co/read/news/2015/04/17/078658512/kemendagri-daerah-wajib-anggarkan-dana-pilkada>.

Akhmedov, A. and E. Zhuravskaya (November 2004) 'Opportunistic Political Cycles: Test in a Young Democracy Setting', Quarterly Journal of Economics 119(4).

Alesina, A. (1987) 'Macroeconomic Policy in a Two-Party System as a Repeated Game', Quarterly Journal of Economics 102(3): 651-678.

Alesina, A. and M. Paradisi (2014) 'Political Budget Cycles: Evidence from Italian Cities', Working paper series. (20570): ALL.

Alt, J.E. and D.D. Lassen (2006) 'Transparency, Political Polarization, and Political Budget Cycles in OECD Countries', American Journal of Political Science 50(3): 530-550.

Arham, M. (Last updated 2015)) 'Simultaneous Regional Elections for a Better Democracy.' Accessed 07/15 $2017<$ http://www.globalindonesianvoices.com/23701/simultaneous-regional-elections-for-a-better-democracy/>.

Aronsson, T. and D. Granlund (2017) 'Federal Subsidization of State Expenditure to Reduce Political Budget Cycles', International Tax and Public Finance 24(3): 536-545.

Arsil, S. (2015) 'Mendagri: 343 Kepala Daerah Tersangkut Kasus Hukum (Minister of Home Affairs: 343 Heads of District Cases of Legal Cases)' Kompas.com, 04/02/2015, .

Aspinall, E. (2014) 'Democratic Deepening in Indonesia: Challenges for the New Administration', Strategic Review .

Balaguer-Coll, M.T., M.I. Brun-Martos, A. Forte and E. Tortosa-Ausina (2015) 'Local Governments' Re-Election and its Determinants: New Evidence Based on a Bayesian Approach', European Journal of Political Economy 39: 94-108http://www.sciencedirect. com/science/article/pii/S0176268015000348.

Baskaran, T., A. Brender, S. Blesse and Y. Reingewertz (2016) 'Revenue Decentralization, Central Oversight and the Political Budget Cycle: Evidence from Israel', European Journal of Political Economy 42(1-2): 1-16.

Bee, C.A. and S.R. Moulton (2015) 'Political Budget Cycles in U.S. Municipalities', Economics of Governance 16(4): 379-403.

Benito, B., F.J.B. Albaladejo and C. Vicente (September 2012) 'Political Budget Cycles in Local Governments', Lex Localis 4(4): 341-361.

Bertelsmann Stiftung's Transformation Index (BTI) (2016) 'BTI 2016: Indonesia Country Report'. Gütersloh: Bertelsmann Stiftung.

Blöndal, e.a. (2009) 'Budgeting in Indonesia', OECD Journal on Budgeting 2009(2). 
Borenstein, M.e.a. (2009) Introduction to Meta-Analysis. London: John Willay and Sons.

Brender, A., A. Drazen and National Bureau of Economic Research. (2004) Political Budget Cycles in New Versus Established Democracies. Cambridge, Massasuchete: National Bureau of Economic Research,.

Brender, A. and A. Drazen (2005) 'Political Budget Cycles in New Versus Established Democracies'. <http://www.sciencedirect.com/science/article/pii/S0304393205000887> (ID: 271711).

Brodjonegoro, B. (2001) 'Indonesian Intergovernmental Transfer in Decentralization Era: The Case of General Allocation Fund., An International Symposium on Intergovernmental Transfers in Asian Countries : Issues and Practices Asian Tax and Public Policy Program, Hitotsubashi University. Tokyo. .

Burden, B.C. (2009) 'The Dynamic Effects of Education on Voter Turnout', Electoral Studies 28(4): 540-549.

C. Pass, B. and L.D. Lowes (Last updated 2005) 'Collins Dictionary of Economics, 4th Ed. S.v. “Government Expenditure.”. Accessed July $292017<$ http://financial-dictionary. thefreedictionary.com/government+expenditure $>$.

Cheema, G.S. and R. D.A. (2007) "From Government Decentralization to Decentralizing Governance", in Cheema, G.S. \& Rondinelli, D.A. (ed.) Decentralising Governance: Emerging Concepts and Practices, pp. 1-20. Washington: The Brookings Institution Press.

Choi, N. (2007) 'Elections, Parties and Elites in Indonesia's Local Politics', South East Asia Research 15(3): 325-354.

Chortareas, G., V. Logothetis and A.A. Papandreou (2016) 'Political Budget Cycles and Reelection Prospects in Greece's Municipalities', European Journal of Political Economy 43: 1-13.

Director Generale of Regional Autonomy and Ministry of Home Affairs (Last updated 2015) 'Ministry of Home Affairs Letters no. 120/4474/OTDA on Confirmation of the Last Term of Office of the Head of the Region in 2015' 28/08/2016.

Directorate General Fiscal Balaance, MoF (Last updated 2017) 'Sistem Informasi Keuangan Daerah 2011-2017' (a webpage of Ministry of Finance). Accessed 06/06 $2017<\mathrm{http}: / /$ www.djpk.depkeu.go.id/?page_id=316>.

Directorate General of Regional Autonomy, MoHA (Last updated 2014) 'The Formation of Autonomous Regions Until 2014. Accessed on 22th July 2017'. Accessed 07/22 2017 $<$ http://otda.kemendagri.go.id/CMS/Images/SubMenu/totalDOB.pdf>.

Drazen, A. (2008) 'Political Budget Cycles', in S.N. Durlauf and L.E. Blume (eds) The New Palgrave Dictionary of Economics, (Second Edition edn). Palgrave MacMillan.

Drazen, A. and M. Eslava (2010) 'Electoral Manipulation Via Voter-Friendly Spending: Theory and Evidence', Journal of Development Economics 92(1): 39-52.

Drazen, A. and M. Eslava (2010) 'Electoral Manipulation Via Voter-Friendly Spending: Theory and Evidence, Journal of Development Economics 92(1): 39.

Dubois, E. (2016) 'Political Business Cycles 40 Years After Nordhaus', Public Choice 166(1): 235-259.

Efthyvoulou, G. (2012) 'Political Budget Cycles in the European Union and the Impact of Political Pressures', Public Choice 153(3): 295-327. 
Foremny, D. and N. Riedel (2014) 'Business Taxes and the Electoral Cycle', Journal of Public Economics 115(4): 48-61.

Galli, E. and S.P.S. Rossi (2002) 'Political Budget Cycles: The Case of the Western German LÃander', Public Choice 110(3): 283-303.

Gibbins, R. and P.D. Webb (Last updated 2015) 'Election, accessed on , . (a webpage of Encyclopædia Britannica, inc). Accessed 07/15 2017 <https://www.britannica.com/topic/ election-political-science/Functions-of-elections $>$.

Gonzalez, P. and Centre for Economic Policy Research (Great Britain) (2006) Political Budget Cycles and Fiscal Decentralization. London : Centre for Economic Policy Research,. Gujarati, D.N. (2003) Basic Econometrics. (4th edn) Boston: McGraw Hil.

Hafidz, M. and U.H. Sadikin (2017) Penyelenggaraan Pilkada Serentak 2015 Dan 2017 . Jakarta: KPU-RI.

Hanusch, M. and D.B. Magleby (2014) 'Popularity, Polarization, and Political Budget Cycles', Public Choice 159(3): 457-467.

Hartriani, J. (2014) Wardani, S.B.E. 'Politik Etnis Pada Masa Pemerintahan Gubernur Cornelis Di Kalimantan Barat Tahun 2007 Hingga 2013 (Ethnic Politics in the Governor Cornelis s Governance in West Kalimantan 2007-2013)'. (Bachelor). Jakarta: University of Indonesia.

Henderson, J.V. and A. Kuncoro (2011) 'Corruption and Local Democratization in Indonesia: The Role of Islamic Parties', Journal of Development Economics 94(2): 164.

International Foundation for Electoral System (Last updated n.d.) 'Indonesia's 2015 Regional Elections'. Accessed 01/30 2016 <ww.ifes.org/news/indonesias-2015-regional-elections $>$.

King, Y.D. (2003) Half-Hearted Reform: Electoral Institutions and the Struggle for Democracy in Indonesia. Wesport: Praeger Publishing.

Kis-Katos, K. and B.S. Sjahrir (2014) 'The Impact of Fiscal and Political Decentralization on Local Public Investments in Indonesia, IZA Duscussion Paper Series IZA DP No. 7884: 12 July $2017<$ http://ftp.iza.org/dp7884.pdf>.

Klein, F.a. (2010) 'Reelection Incentives and Political Budget Cycle: Evidence from Brazil', Revista de Administracao Publica : 283-337.

Klein, F.A. and S.N. Sakurai (2015) 'Term Limits and Political Budget Cycles at the Local Level: Evidence from a Young Democracy'. <http://www.sciencedirect.com/science/ article/pii/S0176268014001013> (ID: 271678).

Klomp, J. and J. de Haan (2013) 'Political Budget Cycles and Election Outcomes', Public Choice 157(1): 245-267.

Lindbeck, A. (1976) 'Stabilization Policy in Open Economies with Endogenous Politicians', American Economic Review 66(2): 1-19.

Lucardi, A. and G. Rosas (2016) 'Is the Incumbent Curse the Incumbent's Fault? Strategic Behavior and Negative Incumbency Effects in Young Democracies', Electoral Studies 44(Supplement C): 66-75http://www.sciencedirect.com/science/article/pii/ S026137941630060919/09/2019.

McRae, D. 'Why Direct Local Elections Matter to Indonesia’s Democracy', 2014.

Micom (2016) 'Micom (2016) Pilkada Serentak Dengan Aturan Berbeda (Simultaneous Pilkada with Different Regulations). ' mediaindonesia.com, 20/06, . 
Milligan, K., E. Moretti, P. Oreopoulos and National Bureau of Economic Research. (2003) Does Education Improve Citizenship? Evidence from the U.S. and the U.K. Cambridge, Mass. : National Bureau of Economic Research,

Ministry of Finance, Republic Indonesia (2015) Informasi APBN 2016 (Central Budget of 2016 Information).

Muttaqin, T., M. van Duijn, L. Heyse and R. Wittek (2016) 'The Impact of Decentralization on Educational Attainment in Indonesia', in R.L. Holzhacker, R. Wittek and J. Woltjer (eds) Decentralization and Governance in Indonesia, pp. 79-103. Cham: Springer International Publishing.

Nachrowi, D.N. and H. Usman (2006) Pendekatan Populer Dan Praktis Ekonometrika Untuk Analisis Ekonomi Dan Keuangan (Popular and Practical Approach of Econometrics for Economic and Finance Analysis) . Jakarta: Lembaga Penerbit Fakultas Ekonomi Universitas Indonesia.

Nadeau, R. and A. Blais (1993) 'Accepting the Election Outcome: The Effect of Participation on Losers' Consent', British Journal of Political Science 23(4): 553-563https://www. cambridge.org/core/article/accepting-the-election-outcome-the-effect-of-participation-on-losers-consent/E16721F53BB41E303495BA6FF5339A9C2017/04/12.

Nasution, A. (2016) 'Government Decentralization Program in Indonesia', ADBI Working Paper 601.

Nordhaus, W.D. (1975) ‘The Political Business Cycle', Review of Economic Studies 2: 169-190.

Ostwald K, Tajima Y, Samphantharak K. (2016) 'Indonesia's Decentralization Experiment: Motivations, Successes, and Unintended Consequences. ', Journal of Southeast Asian Economies 33(2): 139-56.

Persson, T. and G. Tabellini (2002) 'Political Economics and Public Finance', in A.J. Auerbach and M. Feldstein (eds) Handbook of Public Economics, Vol. 3. pp. 1549-1659. Elsevier.

Philips, A.Q. (2016) 'Seeing the Forest through the Trees: A Meta-Analysis of Political Budget Cycles', Public Choice 168(3): 313-341.

Republic of Indonesia (2015) 'The Law no. 8 of 2015 on Amendment to Law no. 1 of 2015 on Stipulation of Government Regulation no. 1 of 2014 on the Election of the Governor, Regent, and Mayor be Liable'.

Republic of Indonesia (2014) 'The Law no. 33/2014 regarding Regional Election'.

Ritonga, I.T. and M.I. Alam (2010) 'Apakah Incumbent Memanfaatkan Anggaran Pendapatan Belanja Daerah (APBD) Untuk Mencalonkan Kembali Dalam Pemilihan Umum Kepala Daerah (PEMILUKADA)', Simposium Nasional Akutansi XIII: 27 July 2017. Accessed tiepena.ac.id/wp-content/uploads/2011/11/ASP_05.pdf <http://stiepena. ac.id/wp-content/uploads/2011/11/ASP_05.pdf>.

Rogoff, K. and A. Sibert (Jan., 1988) 'Elections and Macroeconomic Policy Cycles', The Review of Economic Studies 55(1): 1-16.

Rosenberg, J. (1992) 'Rationality and the Political Business Cycle: The Case of Local Government', Public Choice (1986-1998) 73(1): 71.

Sakurai, S.N. and N. Menezes-Filho (2011) 'Opportunistic and Partisan Election Cycles in Brazil: A New Evidence at the Municipal Level', Public Choice 148(1): 233-247.

Setiawan, B. (2006) 'Petahana Tetap Kuat Di Pilkada 2015 (the Incumbents have Won in the 
Regional Election in 2015)' 07/01/2016, .

Shi, M. and J. Svensson (2006) 'Political Budget Cycles: Do they Differ Across Countries and Why?', Journal of Public Economics 90(8-9): 1367-1389.

Sjahrir, B.S., K. Kis-Katos and G.G. Schulze (2013) 'Political Budget Cycles in Indonesia at the District Level. <http://www.sciencedirect.com/science/article/pii/ S0165176513002449> (ID: 271682).

Smoke, P. (2007) "Fiscal Decentralisation and Intergovernmental Fiscal Relations: Navigating a Viable Path to Reform", in Cheema, G.S. \& Rondinelli, D.A. (ed.) Decentralising Governance: Emerging Concepts and Practices, pp. 141-142. Washington: The Brookings Institution Press.

Statistics Indonesia (2017) 'Financial Statistics of Regency/Municipality Government 20152016 Book 1 and 2', Financial Statistics Regional Government, No. 06310.1703. Jakarta: BPS.

Streb, J.M., D. Lema and G. Torrens (2009) 'Checks and Balances on Political Budget Cycles: Cross Country Evidence', Kyklos 62(3): 426-447.

Surbakti, R. (January-March 2014) 'Understanding the Flaws in Indonesia's Electoral Democracy', Strategic Review .

Tamang, L.R. (Last updated 2017) 'Five Things You may Not Know about Indonesia's Regional Elections'. Accessed 07/05 2017 <http://www.idea.int/news-media/news/fivethings-you-may-not-know-about-indonesia\%E2\%80\%99s-regional-elections $>$.

Tanjung, B.H. (2015) 'Petahana Kalah Telak Di Pilkada Bengkalis (the Incumbents Heavily Lost in Bengkalis)' www.okezone.com,.

The Supreme Constitutional Court Republic of Indonesia (2015) 'The Supreme Constitutional Court Stipulation Number 100/PUU-XIII/2015'. (http://ppid.kpu.go.id/?download $=20151215085544)$.

Ul Haq, M.F. (2017) 'ICW Ungkap Keterkaitan Dinasti Politik, Pilkada, Dan Korupsi (ICW Discloses the Linkage of Political Election, and Corruption Dynasties)' detiknews. com, 22/01/2017, .

Veiga, L.G. and F.J. Veiga (2007) 'Does Opportunism Pay Off?', Economics Letters 96(2): 177182.

Vergne, C. (2009) 'Democracy, Elections and Allocation of Public Expenditures in Developing Countries'. <http://www.sciencedirect.com/science/article/pii/S0176268008000748> (ID: 271678).

Vicente, C., B. Benito and F. Bastida (2013) 'Transparency and Political Budget Cycles at Municipal Level', Swiss Political Science Review 19(2): 139-156.

Wardhani, D.A. (2014) 'Ahok Defends Direct Elections, Slams Coalition. Accessed 20 August 2017' www.thejakartapost.com, 09/09/2014.

Winoto, A.H. and Falikhatun (Juni 2015) 'Indikasi Penyalahgunaan Discretionary Fund Dalam Anggaran Pendapatan Dan Belanja Daerah Menjelang Pemilukada 2015’, Jurnal Akuntansi dan Keuangan Indonesia 12(1): 75 - 91.

Wiseno (Last updated 2017) 'Simultaneous Regional Elections Expected to Boost Economic Growth' 07/15 <http://www.en.netralnews.com/news/business/read/108/simultaneous.regional.elections.expected.to.boost.economic.growth>. 